\title{
Low serum magnesium is associated with faster decline in kidney function: the Dallas Heart Study experience
}

\author{
Silvia Ferrè, ${ }^{\oplus 1,2}$ Xilong Li, ${ }^{3}$ Beverley Adams-Huet, ${ }^{1,3}$ Naim M Maalouf, 1,2 \\ Khashayar Sakhaee, ${ }^{1,2}$ Robert D Toto, ${ }^{3,4}$ Orson W Moe, ${ }^{1,4,5}$ Javier A Neyra ${ }^{1,2,6}$
}

For numbered affiliations see end of article.

\section{Correspondence to} Dr Silvia Ferrè, Department of Internal Medicine, UT Southwestern Medical Center, Dallas TX 75390, USA:

silvia.ferre@utsouthwestern. edu and Dr Javier A Neyra, Department of Internal Medicine, Division of Nephrology, Bone, and Mineral Metabolism, University of Kentucky, 800 Rose St, MN668, Lexington, KY, 40536, USA; javier.neyra@uky.edu

Accepted 24 January 2019 Published Online First 2 March 2019

\section{Check for updates}

(C) American Federation for Medical Research 2019. No commercial re-use. See rights and permissions. Published by BMJ.

To cite: Ferrè $S$ Li X, Adams-Huet B, et al. J Investig Med 2019;67:987-994.

\section{ABSTRACT}

Hypomagnesemia associates with inflammation and risk of diabetes and hypertension, which may contribute to kidney function decline. We hypothesized that low serum magnesium (SMg) levels independently associate with a significant decline in estimated glomerular filtration rate (eGFR). We analyzed SMg levels in 2056 participants from the Dallas Heart Study, a longitudinal, populationbased, multiethnic, cohort study involving residents of Dallas County, Texas, USA. The primary study outcome was the change in eGFR using multivariable linear regression models adjusted for demographics, anthropometric and biochemical parameters, medications, $C$ reactive protein levels, prevalent hypertension and diabetes. During a median followup of 7.0 years ( 25 th, 75 th percentile: $6.5,7.6)$, the median decrease in eGFR was -0.71 (25th, 75th percentile: $-2.43,+0.68) \mathrm{mL} / \mathrm{min} / 1.73 \mathrm{~m}^{2}$ per year in the entire cohort. In a fully adjusted model, the lowest SMg quintile ( $\leq 1.9 \mathrm{mg} / \mathrm{dL}$ or $\leq 0.8 \mathrm{mM}$ ) was associated with a $-0.50 \mathrm{~mL} / \mathrm{min} / 1.73 \mathrm{~m}^{2}$ per year drop in eGFR ( $95 \% \mathrm{Cl}-0.95$ to $-0.05 ; \mathrm{p}=0.028)$ compared with the highest SMg quintile $(\geq 2.3 \mathrm{mg} /$ $\mathrm{dL}$ or $\geq 1.0 \mathrm{mM})$. Every $0.2 \mathrm{mg} / \mathrm{dL}(0.08 \mathrm{mM})$ decrease in SMg was associated with an eGFR decline of $-0.23 \mathrm{~mL} / \mathrm{min} / 1.73 \mathrm{~m}^{2}$ per year $(95 \% \mathrm{Cl}$ -0.38 to $-0.08 ; p=0.003)$, a decline that was more pronounced in participants with prevalent diabetes compared with patients without diabetes $(-0.51$ vs $-0.18 \mathrm{~mL} / \mathrm{min} / 1.73 \mathrm{~m}^{2}$ per year, respectively). In conclusion, low SMg was independently associated with eGFR decline. Further studies are needed to determine whether $\mathrm{Mg}$ repletion can ameliorate inflammation, lower blood pressure and serum glucose and ultimately prevent or retard kidney function decline.

\section{INTRODUCTION}

Chronic kidney disease (CKD) is a global public health problem with an overall prevalence in the general population of approximately 14\%-20\%. ${ }^{12}$ Diabetes and hypertension are major risk factors for the development of CKD and nearly two-thirds of cases of end-stage renal disease (ESRD) in the USA are attributed to these underlying prevalent conditions. ${ }^{3}$ The mechanisms governing CKD onset and progression

\section{Significance of this study}

What is already known about this subject?

- Both low magnesium (Mg) intake and low serum $\mathrm{Mg}(\mathrm{SMg})$ levels are associated with an increased incidence of diabetes and hypertension, two major risk factors for the development of chronic kidney disease (CKD).

- Low SMg levels independently associate with incidence and progression of CKD after controlling for potential socioeconomic and clinical confounders of kidney function decline.

- Mg supplementation inhibits the expression of profibrotic and proinflammatory cytokines in endothelial and renal tubular cells in vitro.

What are the new findings?

- This is the first study to show that every $0.2 \mathrm{mg} / \mathrm{dL}(0.08 \mathrm{mM})$ decrease in SMg was independently associated with an estimated glomerular filtration rate (eGFR) decline of $-0.23 \mathrm{~mL} / \mathrm{min} / 1.73 \mathrm{~m}^{2}$ per year $(95 \% \mathrm{Cl}-0.38$ to $-0.08 ; p=0.003)$ in a multiethnic cohort with approximately $50 \%$ African-Americans.

- The lowest SMg quintile $(\leq 1.9 \mathrm{mg} /$ $\mathrm{dL}$ or $\leq 0.8 \mathrm{mM}$ ) was associated with a $-0.50 \mathrm{~mL} / \mathrm{min} / 1.73 \mathrm{~m}^{2}$ per year drop in eGFR $(95 \% \mathrm{Cl}-0.95$ to $-0.05 ; p=0.028)$ compared with the highest SMg quintile ( $\geq 2.3 \mathrm{mg} / \mathrm{dL}$ or $\geq 1.0 \mathrm{mM}$ ).

- The eGFR decline was more pronounced in participants with prevalent diabetes compared with patients without diabetes $\left(-0.51\right.$ vs $-0.18 \mathrm{~mL} / \mathrm{min} / 1.73 \mathrm{~m}^{2}$ per year, respectively).

How might these results change the focus of research or clinical practice?

- The modulation of SMg levels through $\mathrm{Mg}$ supplementation could represent a novel therapeutic target for the prevention of kidney function decline in patients with and without diabetes, who are at high risk of developing CKD. 
are only partially understood. Besides early detection by biomarkers of kidney dysfunction or injury, the identification of novel risk factors for incidence or progression of CKD may improve our understanding of the pathogenesis of CKD, allow more accurate risk stratification and lead to the development of new therapies.

Magnesium ( $\mathrm{Mg}$ ) is essential for human health, being the second most abundant intracellular cation after potassium, and is involved in virtually every biologic process in the cell. ${ }^{4}$ In the general population, both low $\mathrm{Mg}$ intake and low serum $\mathrm{Mg}$ (SMg) levels are associated with an increased incidence of diabetes, ${ }^{5}$ hypertension, ${ }^{6}$ metabolic syndrome, $^{7}$ inflammation $^{8}{ }^{9}$ and cardiovascular disease (CVD). ${ }^{10-13}$ Hypomagnesemia is postulated to contribute to the development of diabetes by impairing the insulin receptor downstream signaling and increasing inflammation, ${ }^{14-16}$ which further increases insulin resistance. In addition, both in vivo and in vitro studies showed that hypomagnesemia may increase blood pressure and promote CVD by enhancing the production of vasoconstrictor agents and cytokines (eg, endothelin-1 and interleukin-8), ${ }^{17} 18$ decreasing the production of endothelial-derived vasodilators (eg, prostacyclin and nitric oxide) ${ }^{19} 20$ and increasing oxidative stress. ${ }^{21}$ Observational studies have shown that low SMg levels independently associate with incidence and progression of CKD in patients with or without diabetes, ${ }^{22-26}$ as well as cardiovascular events and mortality in patients with CKD or undergoing hemodialysis. ${ }^{27-32}$ The molecular

Table 1 Baseline characteristics of study participants at DHS-1 in the entire cohort according to serum magnesium quintiles (mg/dL)

\begin{tabular}{|c|c|c|c|c|c|c|c|}
\hline Characteristics & $\begin{array}{l}\text { Entire cohort } \\
n=2056\end{array}$ & $\begin{array}{l}Q 1 \\
\leq 1.9 \\
n=460\end{array}$ & $\begin{array}{l}Q 2 \\
2.0 \\
n=440\end{array}$ & $\begin{array}{l}\text { Q3 } \\
2.1 \\
n=483\end{array}$ & $\begin{array}{l}Q 4 \\
2.2 \\
n=403\end{array}$ & $\begin{array}{l}Q 5 \\
\geq 2.3 \\
n=270\end{array}$ & P trend \\
\hline \multicolumn{8}{|l|}{ Demographics } \\
\hline Age, years & $44.2 \pm 10.0$ & $42.9 \pm 10.3$ & $43.4 \pm 9.7$ & $43.9 \pm 9.6$ & $45.1 \pm 10.2$ & $46.5 \pm 9.8$ & $<0.001$ \\
\hline Gender (male), \% & 41.9 & 26.5 & 41.6 & 42.2 & 51.6 & 53.7 & $<0.001$ \\
\hline Race, \% & & & & & & & $<0.001$ * \\
\hline Hispanic & 14.0 & 11.3 & 13.4 & 15.1 & 15.1 & 15.9 & \\
\hline Non-Hispanic black & 48.9 & 65.9 & 53.0 & 45.8 & 37.7 & 35.6 & \\
\hline Non-Hispanic white & 35.1 & 22.0 & 33.2 & 35.2 & 44.9 & 45.6 & \\
\hline $\mathrm{BMI}, \mathrm{kg} / \mathrm{m}^{2}$ & $30.5 \pm 7.5$ & $31.8 \pm 8.5$ & $30.5 \pm 7.3$ & $30.4 \pm 7.8$ & $30.0 \pm 6.7$ & $29.1 \pm 6.0$ & $<0.001$ \\
\hline \multicolumn{8}{|l|}{ Comorbidities } \\
\hline Prevalent diabetes, \% & 9.1 & 18.5 & 8.9 & 5.4 & 7.0 & 3.3 & $<0.001$ \\
\hline Prevalent hypertension, \% & 37.2 & 42.8 & 34.8 & 34.2 & 34.2 & 41.1 & 0.27 \\
\hline $\mathrm{SBP}, \mathrm{mm} \mathrm{Hg}$ & $126.8 \pm 17.8$ & $127.2 \pm 18.0$ & $125.9 \pm 17.6$ & $126.1 \pm 17.2$ & $127.4 \pm 19.2$ & $128.1 \pm 17.1$ & 0.45 \\
\hline DBP, mm Hg & $79.0 \pm 9.9$ & $79.0 \pm 9.6$ & $78.9 \pm 10.1$ & $78.6 \pm 9.4$ & $79.0 \pm 10.7$ & $79.9 \pm 9.8$ & 0.66 \\
\hline Current smoker, \% & 25.8 & 27.5 & 28.7 & 25.1 & 23.6 & 23.0 & $0.009^{*}$ \\
\hline Current alcohol user, \% & 71.4 & 66.7 & 72.7 & 72.5 & 74.4 & 71.0 & $0.12^{*}$ \\
\hline \multicolumn{8}{|l|}{ Medications } \\
\hline Diuretics, \% & 9.1 & 12.2 & 6.4 & 8.7 & 8.7 & 9.3 & 0.32 \\
\hline ACEI, \% & 17.5 & 22.8 & 17.0 & 16.8 & 15.1 & 14.1 & 0.001 \\
\hline$A R B, \%$ & 9.5 & 11.1 & 8.6 & 8.5 & 9.4 & 10.4 & 0.73 \\
\hline Dietary supplements, \% & 23.7 & 18.7 & 23.0 & 23.4 & 28.5 & 26.7 & 0.001 \\
\hline \multicolumn{8}{|l|}{ Laboratory values } \\
\hline Magnesium, mg/dL & $2.1 \pm 0.2$ & $1.8 \pm 0.1$ & $2.0 \pm 0.0$ & $2.1 \pm 0.0$ & $2.2 \pm 0.0$ & $2.4 \pm 0.1$ & \\
\hline $\mathrm{eGFR}, \mathrm{mL} / \mathrm{min} / 1.73 \mathrm{~m}^{2}$ & $99.9 \pm 20.7$ & $105.5 \pm 22.4$ & $101.1 \pm 20.0$ & $98.7 \pm 19.8$ & $97.7 \pm 21.0$ & $93.8 \pm 17.7$ & $<0.001$ \\
\hline$\triangle \mathrm{eGFR}, \mathrm{mL} / \mathrm{min} / 1.73 \mathrm{~m}^{2}$ per year & $-0.7(-2.4,0.7)$ & $-1.1(-3.1,0.5)$ & $-0.8(-2.5,0.7)$ & $-0.6(-2.2,0.9)$ & $-0.6(-2.2,0.6)$ & $-0.5(-2.0,1.0)$ & $<0.001$ \\
\hline Urine ACR, mg/g & $2.7(1.8,4.5)$ & $2.9(1.9,4.9)$ & $2.8(1.8,4.9)$ & $2.6(1.7,4.6)$ & $2.7(1.8,4.1)$ & $2.5(1.8,3.9)$ & 0.009 \\
\hline Albumin, g/dL & $4.0 \pm 0.3$ & $3.8 \pm 0.3$ & $4.0 \pm 0.3$ & $4.0 \pm 0.3$ & $4.1 \pm 0.3$ & $4.1 \pm 0.3$ & $<0.001$ \\
\hline Glucose, mg/dL & $100.5 \pm 37.9$ & $113.2 \pm 60.6$ & $99.9 \pm 37.8$ & $96.0 \pm 23.0$ & $96.9 \pm 23.1$ & $93.2 \pm 16.7$ & 0.08 \\
\hline Calcium, mg/dL & $9.2 \pm 0.4$ & $9.2 \pm 0.4$ & $9.2 \pm 0.4$ & $9.2 \pm 0.4$ & $9.3 \pm 0.3$ & $9.3 \pm 0.4$ & $<0.001$ \\
\hline Phosphate, mg/dL & $3.2 \pm 0.6$ & $3.2 \pm 0.6$ & $3.2 \pm 0.5$ & $3.2 \pm 0.5$ & $3.2 \pm 0.6$ & $3.2 \pm 0.7$ & 0.32 \\
\hline Sodium, mEq/L & $137.7 \pm 2.4$ & $136.9 \pm 2.4$ & $137.6 \pm 2.3$ & $137.7 \pm 2.3$ & $138.2 \pm 2.4$ & $138.3 \pm 2.5$ & $<0.001$ \\
\hline Potassium, mEq/L & $4.3 \pm 1.7$ & $4.2 \pm 1.6$ & $4.4 \pm 1.4$ & $4.3 \pm 1.8$ & $4.2 \pm 2.1$ & $4.5 \pm 1.6$ & $<0.001$ \\
\hline Bicarbonate, mEq/L & $27.2 \pm 2.2$ & $26.8 \pm 2.2$ & $27.1 \pm 2.1$ & $27.1 \pm 2.2$ & $27.5 \pm 2.1$ & $27.7 \pm 2.3$ & $<0.001$ \\
\hline iPTH, pg/mL & $37.2(28.3,49.9)$ & $35.8(26.1,49.1)$ & $38.0(28.7,48.6)$ & $37.2(28.7,50.2)$ & $37.1(29.1,51.1)$ & $38.2(29.2,52.1)$ & 0.01 \\
\hline Total cholesterol, mg/dL & $180.6 \pm 37.8$ & $172.9 \pm 38.3$ & $181.4 \pm 36.6$ & $181.2 \pm 37.1$ & $181.3 \pm 36.8$ & $190.6 \pm 38.8$ & $<0.001$ \\
\hline $\mathrm{HDL}, \mathrm{mg} / \mathrm{dL}$ & $50.4 \pm 14.6$ & $52.1 \pm 15.5$ & $51.1 \pm 14.5$ & $50.6 \pm 14.5$ & $48.1 \pm 13.7$ & $49.5 \pm 14.6$ & 0.001 \\
\hline CRP, mg/L & $2.7(1.1,6.4)$ & $3.2(1.0,8.4)$ & $2.7(1.1,6.6)$ & $2.7(1.2,6.7)$ & $2.2(0.9,5.3)$ & $2.5(1.1,4.9)$ & $<0.001$ \\
\hline
\end{tabular}

${ }^{*} \chi^{2}$ Data are presented as mean $\pm S D$, median (25th, 75 th percentile) or per cent for categorical variables.

eGFR was calculated according to the MDRD study equation. Microalbuminuria was calculated as ACR. Dietary supplements consisted of any combination or single treatment with $\mathrm{Mg}$, calcium, active vitamin D and/or multivitamins. Conversion factors for units: phosphate in $\mathrm{mg} / \mathrm{dL}$ to $\mathrm{mmol} / \mathrm{L}, \times 0.3229$; calcium in $\mathrm{mg} / \mathrm{dL}$ to $\mathrm{mmol} / \mathrm{L}$, $\times 0.2495$; cholesterol in $\mathrm{mg} / \mathrm{dL}$ to $\mathrm{mmol} / \mathrm{L}, \times 0.02586 ; \mathrm{HDL}$ in $\mathrm{mg} / \mathrm{dL}$ to $\mathrm{mmol} / \mathrm{L}, \times 0.0258$.

ACEl, ACE inhibitors; ACR, microalbumin/creatinine ratio; $A R B$, angiotensin II receptor blockers; BMI, body mass index; $B$, blood pressure; CRP, C reactive protein; DHS, Dallas Heart Study; eGFR, estimated glomerular filtration rate; HDL, high-density lipoprotein; iPTH, intact parathyroid hormone. 
Table 2 Analysis of the cross-sectional correlations relevant to this study in the entire cohort at DHS-1 (baseline)

\begin{tabular}{lccc}
\hline \multirow{4}{*}{$\begin{array}{l}\text { Spearman's correlation coefficients Prob>r under } \\
\text { HO: Rho=0 }\end{array}$} & \multicolumn{1}{l}{ SMg } \\
\cline { 2 - 4 } & $\Delta$ eGFR & CRP & 1.00 \\
\hline SMg & 0.09 & -0.08 & - \\
& $<0.001$ & $<0.001$ & -0.04 \\
SBP & -0.09 & 0.24 & 0.09 \\
& $<0.001$ & $<0.001$ & -0.04 \\
DBP & -0.04 & 0.23 & 0.04 \\
& 0.11 & $<0.001$ & -0.04 \\
SGlu & -0.05 & 0.23 & 0.04 \\
& 0.02 & $<0.001$ & 0.09 \\
SeGFR & 1.00 & -0.03 & $<0.001$ \\
\hline
\end{tabular}

Spearman's correlation coefficients (top) and $\mathrm{p}$ values (bottom) are reported. CRP, C reactive protein; DBP, diastolic blood pressure; DHS, Dallas Heart Study; DHS-1, DHS phase 1 (2000-2002); $\triangle \mathrm{eGFR}$, eGFR at DHS-2 minus eGFR at DHS-1; eGFR, estimated glomerular filtration rate; SBP, systolic blood pressure; $\mathbf{S G l u}$, serum glucose; $\mathrm{SMg}$, serum magnesium.

mechanisms underlying possible deleterious effects of low $\mathrm{SMg}$ on renal function are largely unknown.

In this study, we tested the hypothesis that low SMg levels are independently associated with kidney function decline in the Dallas Heart Study (DHS) cohort participants who did not have CKD at baseline. The DHS is a large multiethnic population characterized by standardized longitudinal data collection methodology with a comprehensive biochemical phenotype assessment, and the availability of biomarkers of inflammation, blood pressure and glycemic parameters.

\section{MATERIALS AND METHODS \\ Study population}

The DHS is a multiethnic, population-based, cohort study of Dallas County adults aged 30-65 years in which deliberate oversampling of African-Americans was performed. Written informed consent was provided by all participants. Baseline data collection during DHS phase 1 (DHS-1) was conducted in three visits between 2000 and 2002. The design and detailed methods of DHS-1 have been previously described. ${ }^{33}$ In DHS phase 2 (DHS-2), participants who already completed DHS-1 underwent follow-up testing in a single visit to UT Southwestern Medical Center between 2007 and 2009. Participants were followed for predefined clinical events and death. For this study, the observation period was 7.0 years $(25$ th, 75 th percentile: $6.5,7.6)$. We excluded participants with prevalent CKD $(n=244)$ to avoid confounding effects from comorbidity, those with missing SMg measurements at DHS-1 $(n=6)$ and/or with missing serum creatinine levels at either DHS-1 or DHS-2 $(\mathrm{n}=1382)$, resulting in a final cohort of 2056 participants. According to the latest Kidney Disease Improving Global Outcomes (KDIGO) guidelines, prevalent CKD at DHS-1 was defined as an microalbumin/creatinine ratio $\geq 30 \mathrm{mg} / \mathrm{g}$ and/or an eGFR $<60 \mathrm{~mL} / \mathrm{min} / 1.73 \mathrm{~m}^{2} .^{3}$ The number of deaths that occurred during the follow-up period was limited to 241 and baseline SMg levels were clinically comparable in those excluded because of death and all

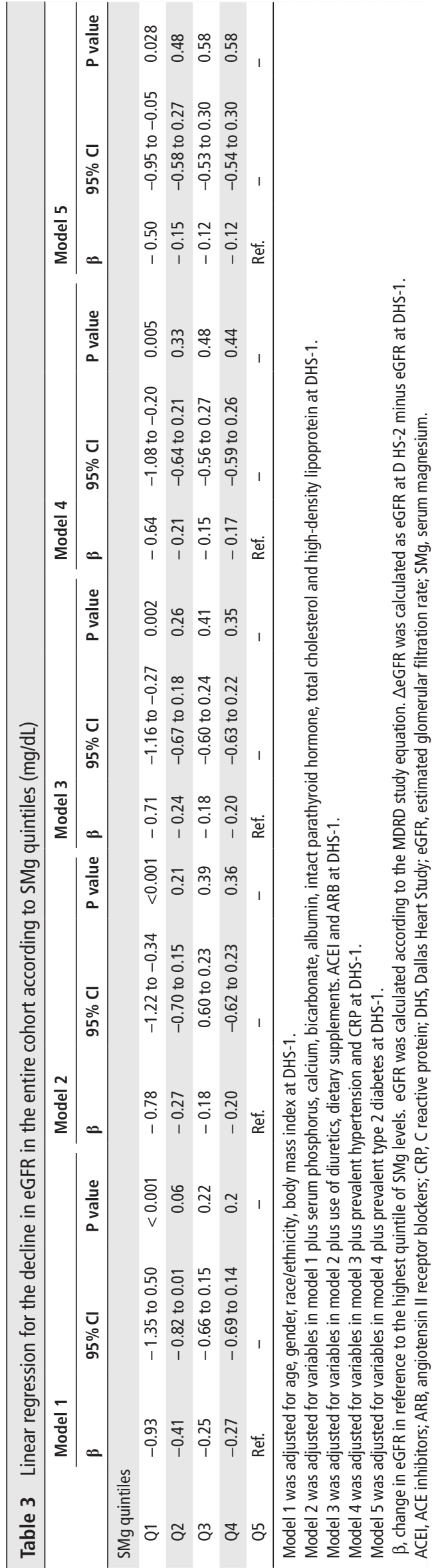


Table 4 Baseline characteristics of participants without and with prevalent diabetes at DHS

\begin{tabular}{|c|c|c|c|}
\hline \multirow[b]{2}{*}{ Characteristics } & \multirow{2}{*}{$\begin{array}{l}\text { Without prevalent } \\
\text { DM } \\
(n=1869)\end{array}$} & \multirow{2}{*}{$\begin{array}{l}\text { With prevalent DM } \\
(n=187)\end{array}$} & \multirow[b]{2}{*}{$P$ value } \\
\hline & & & \\
\hline \multicolumn{4}{|l|}{ Demographics } \\
\hline Age, years & $43.5 \pm 9.9$ & $50.4 \pm 8.8$ & $<0.001$ \\
\hline Gender (male), \% & 42.1 & 40.6 & 0.71 \\
\hline Race & & & $<0.001 *$ \\
\hline Hispanic & 13.9 & 15.4 & \\
\hline Non-Hispanic black & 47.2 & 65.2 & \\
\hline Non-Hispanic white & 37 & 17.1 & \\
\hline $\mathrm{BMI}, \mathrm{kg} / \mathrm{m}^{2}$ & $29.9 \pm 7.2$ & $35.9 \pm 8.2$ & $<0.001$ \\
\hline \multicolumn{4}{|l|}{ Comorbidities } \\
\hline Prevalent hypertension (\%) & 33.7 & 72.2 & $<0.001$ \\
\hline $\mathrm{SBP}, \mathrm{mm} \mathrm{Hg}$ & $125.8 \pm 17.6$ & $136.9 \pm 17.3$ & $<0.001$ \\
\hline $\mathrm{DBP}, \mathrm{mm} \mathrm{Hg}$ & $78.8 \pm 9.9$ & $81.5 \pm 9.1$ & $<0.001$ \\
\hline Current smoker, \% & 25.8 & 25.7 & $0.95^{*}$ \\
\hline Current alcohol user, $\%$ & 73.4 & 51.4 & $<0.001$ * \\
\hline \multicolumn{4}{|l|}{ Medications } \\
\hline Diuretics, \% & 7.3 & 26.2 & $<0.001$ \\
\hline ACEI, \% & 15.2 & 40.6 & $<0.001$ \\
\hline ARB, \% & 7.5 & 30 & $<0.001$ \\
\hline Dietary supplements, \% & 24.3 & 17.1 & 0.03 \\
\hline \multicolumn{4}{|l|}{ Laboratory values } \\
\hline Magnesium, mg/dL & $2.08 \pm 0.17$ & $1.96 \pm 0.20$ & $<0.001$ \\
\hline eGFR, $\mathrm{mL} / \mathrm{min} / 1.73 \mathrm{~m}^{2}$ & $99.4 \pm 20.3$ & $104.6 \pm 24.2$ & 0.01 \\
\hline $\begin{array}{l}\triangle \mathrm{eGFR}, \mathrm{mL} / \mathrm{min} / 1.73 \mathrm{~m}^{2} \text { per } \\
\text { year }\end{array}$ & $-0.6(-2.3,0.7)$ & $-2.0(-3.8,-0.1)$ & $<0.001$ \\
\hline Urine $A C R, \mathrm{mg} / \mathrm{g}$ & $2.7(1.8-4.3)$ & $3.4(1.9-8.1)$ & $<0.001$ \\
\hline Albumin, g/dL & $4.0 \pm 0.3$ & $3.8 \pm 0.3$ & $<0.001$ \\
\hline Glucose, mg/dL & $91.9 \pm 11.7$ & $185.9 \pm 80.3$ & $<0.001$ \\
\hline Calcium, mg/dL & $9.2 \pm 0.4$ & $9.3 \pm 0.3$ & 0.73 \\
\hline Phosphate, mg/dL & $3.2 \pm 0.5$ & $3.3 \pm 0.6$ & 0.07 \\
\hline Sodium, mEq/L & $137.8 \pm 2.3$ & $136.5 \pm 2.8$ & $<0.001$ \\
\hline Potassium, $\mathrm{mEq} / \mathrm{L}$ & $4.3 \pm 1.8$ & $4.4 \pm 1.3$ & 0.31 \\
\hline Bicarbonate, $\mathrm{mEq} / \mathrm{L}$ & $27.1 \pm 2.2$ & $27.6 \pm 2.3$ & 0.003 \\
\hline iPTH, pg/mL & $37.3(28.4,49.6)$ & $34.6(26.8,51.2)$ & 0.19 \\
\hline Total cholesterol, mg/dL & $180.1 \pm 36.8$ & $186.5 \pm 45.8$ & 0.17 \\
\hline $\mathrm{HDL}, \mathrm{mg} / \mathrm{dL}$ & $50.8 \pm 14.8$ & $46.6 \pm 12.8$ & $<0.001$ \\
\hline $\mathrm{CRP}, \mathrm{mg} / \mathrm{L}$ & $2.4(1.0,5.7)$ & $6.8(2.4,14.3)$ & $<0.001$ \\
\hline
\end{tabular}

${ }^{*} \chi^{2}$ Data are presented as mean $\pm S D$, median $(25$ th, 75 th percentile) or per cent for categorical variables.

eGFR was calculated according to theMDRD study equation. Microalbuminuria was calculated as ACR. Dietary supplements consisted of any combination or single treatment with $\mathrm{Mg}$, calcium, active vitamin D and/or multivitamins. Conversion factors for units: phosphate in $\mathrm{mg} /$ $\mathrm{dL}$ to $\mathrm{mmol} / \mathrm{L}, \times 0.3229 ; \mathrm{HDL}$ in $\mathrm{mg} / \mathrm{dL}$ to $\mathrm{mmol} / \mathrm{L}, \times 0.02586$.

ACEI, ACE inhibitors; ACR, microalbumin/creatinine ratio; $A R B$, angiotensin II receptor blockers; $\mathrm{BMI}$, body mass index; BP, blood pressure; CRP, C reactive protein; DHS, Dallas Heart Study; eGFR, estimated glomerular filtration rate; HDL, high-density lipoprotein; iPTH, intact parathyroid hormone.

survivors at DHS-2 included in the study. Moreover, there were no major differences in medical history, demographics or biomarker data between eligible DHS-1 participants who did and did not complete DHS-2 (follow-up). ${ }^{34}$

\section{Independent variable/predictor}

The exposure of interest was SMg at DHS-1 analyzed according to statistical quintiles or as a continuous variable per $0.2 \mathrm{mg} / \mathrm{dL}$ decline. $\mathrm{SMg}$ was measured in the UT Southwestern General Clinical Research Center laboratory using a SYNCHRON CX9 ALX system (Beckman Coulter,
Fullerton, California, USA) (normal SMg range: $1.7-2.8 \mathrm{mg}$ / $\mathrm{dL}$ or $0.69-1.15 \mathrm{mM}$ ).

\section{Primary study outcome}

The primary study outcome was the change in eGFR ( $\triangle \mathrm{eGFR})$ during the observation period calculated as the values at DHS-2 minus the values at DHS-1. eGFR was estimated using the four-variable Modification of Diet in Renal Disease equation (p. 63). ${ }^{35}$

\section{Variable definitions and measurements}

Race/ethnicity and medication usage were self-reported. Prevalent hypertension $(n=764)$ at DHS-1 was defined by need for pharmacological treatment for hypertension, or a systolic blood pressure (SBP) of $\geq 140 \mathrm{~mm} \mathrm{Hg}$ or a diastolic blood pressure (DBP) of $\geq 90 \mathrm{~mm} \mathrm{Hg}$. Prevalent diabetes $(n=187)$ was defined by pharmacological treatment for diabetes, fasting blood glucose $\geq 126 \mathrm{mg} / \mathrm{dL}(7 \mathrm{mM})$ or non-fasting blood glucose level $\geq 200 \mathrm{mg} / \mathrm{dL}$ (11.1 mM). All baseline laboratory parameters were measured from the fasting blood samples obtained at a second in-home visit during DHS- 1 with the exception of $n=45$ samples that were obtained non-fasting. High-sensitive $C$ reactive protein (CRP) measurements were performed using the Roche/Hitachi 912 System, Tina-quant assay (Roche Diagnostics, Indianapolis, Indiana, USA), a latex-enhanced immunoturbidimetric method. ${ }^{36}$ Diuretic use included thiazide-like diuretics, loop diuretics, potassium-sparing diuretics and/or aldosterone antagonists. Dietary supplements consisted of any combination or single treatment with $\mathrm{Mg}$, calcium, vitamin $\mathrm{D}$ and/or multivitamins.

\section{Statistical analysis}

Baseline characteristics at DHS-1 in the entire cohort stratified by SMg quintiles were analyzed by Jonckheere-Terpstra and Cochran-Armitage for continuous and dichotomous categorical variables, respectively. Data are presented as the mean \pm SD or median (25th, 75 th percentile) for continuous variables and as the number (\%) for categorical variables, respectively. To investigate the relationship between SBP, DBP, serum glucose (SGlu), $\Delta \mathrm{eGFR}, \mathrm{CRP}$ and SMg levels, Spearman's correlation analysis was performed. Multivariable linear regression models were constructed to examine the association between baseline $\mathrm{SMg}$ and the study outcome of $\triangle \mathrm{eGFR}$. Model 1 was adjusted for age, gender, race/ethnicity and body mass index (BMI). Model 2 was adjusted for variables in model 1 plus serum phosphorus, calcium, bicarbonate, albumin, intact parathyroid hormone, total cholesterol and high-density lipoprotein. Model 3 was adjusted for variables in model 2 plus use of diuretics, dietary supplements, ACE inhibitors (ACEI) and angiotensin II receptor blockers (ARB). Model 4 was adjusted for variables in model 3 plus prevalent hypertension and CRP at DHS-1. Model 5 was adjusted for variables in model 4 plus prevalent diabetes at DHS-1. For interaction analyses, a $p$ value of $<0.10$ was considered to be statistically significant. All other statistical analyses used two-sided $\alpha$-values at the significance level of 0.05. Analyses were performed using SAS V.9.4 (Cary, North Carolina, USA). 
Table 5 Analysis of the cross-sectional correlations relevant to this study in participants without and with prevalent diabetes at DHS-1

\begin{tabular}{|c|c|c|c|c|c|c|}
\hline & \multicolumn{6}{|c|}{ Spearman's correlation coefficients Prob $>$ r under HO: $\mathrm{Rho}=0$} \\
\hline & \multicolumn{3}{|c|}{ Without prevalent DM } & \multicolumn{3}{|c|}{ With prevalent DM } \\
\hline & $\triangle \mathrm{eGFR}$ & CRP & SMg & $\triangle \mathrm{eGFR}$ & CRP & SMg \\
\hline \multirow[t]{2}{*}{$\mathrm{SMg}$} & 0.06 & -0.04 & 1.00 & 0.25 & -0.14 & 1.00 \\
\hline & 0.01 & 0.06 & & $<0.001$ & 0.06 & - \\
\hline \multirow[t]{2}{*}{ SBP } & -0.05 & 0.21 & -0.00 & -0.10 & 0.15 & 0.03 \\
\hline & 0.02 & $<0.001$ & 0.99 & 0.16 & 0.04 & 0.66 \\
\hline \multirow[t]{2}{*}{ DBP } & -0.02 & 0.21 & -0.02 & -0.01 & 0.14 & 0.06 \\
\hline & 0.39 & $<0.001$ & 0.29 & 0.90 & 0.05 & 0.43 \\
\hline \multirow[t]{2}{*}{ SGlu } & 0.004 & 0.15 & 0.06 & -0.22 & 0.20 & -0.37 \\
\hline & 0.86 & $<0.001$ & 0.01 & 0.003 & 0.007 & $<0.001$ \\
\hline \multirow[t]{2}{*}{$\triangle \mathrm{eGFR}$} & 1.00 & 0.004 & 0.06 & 1.00 & -0.05 & 0.25 \\
\hline & - & 0.87 & 0.01 & & 0.47 & $<0.001$ \\
\hline
\end{tabular}

Spearman's correlation coefficients (top) and $\mathrm{p}$ values (bottom) are reported.

CRP, C reactive protein; DBP, diastolic blood pressure; DHS, Dallas Heart Study; DHS-1, DHS phase 1 (2000-2002); $\triangle \mathrm{eGFR,} \mathrm{eGFR} \mathrm{at} \mathrm{DHS-2} \mathrm{minus} \mathrm{eGFR} \mathrm{at} \mathrm{DHS-}$

1; eGFR, estimated glomerular filtration rate; SBP, systolic blood pressure; SGlu, serum glucose; SMg, serum magnesium.

\section{RESULTS}

\section{Baseline characteristics}

Of the 2056 participants without pre-existing CKD who had SMg measurements at DHS-1 (baseline) and serum creatinine measurements available both at DHS-1 and DHS-2 (follow-up visit), 41.9\% were male, $48.9 \%$ were black, $35.1 \%$ were white and $14 \%$ were Hispanic (table 1). Mean baseline eGFR \pm SD in the entire cohort was $99.9 \pm 20.7 \mathrm{~mL} /$ $\mathrm{min} / 1.73 \mathrm{~m}^{2}$ at DHS-1 (table 1), and $93.5 \pm 22.7 \mathrm{~mL} /$ $\mathrm{min} / 1.73 \mathrm{~m}^{2}$ at DHS-2 (data not shown). The prevalence of diabetes and hypertension were $9.1 \%$ and $37.3 \%$, respectively. $\mathrm{SMg}$ was normally distributed with a mean \pm SD value of $2.10 \pm 0.20 \mathrm{mg} / \mathrm{dL}(0.86 \pm 0.08 \mathrm{mM})$ in the entire cohort. The comparison of baseline characteristics according to $\mathrm{SMg}$ quintiles revealed that patients in the lowest $\mathrm{SMg}$ quintile were mostly female (73.5\%), included a greater proportion of non-Hispanic black (65.9\%), and had a higher prevalence of diabetes (18.5\%) and hypertension (42.8\%; table 1). Consequently, the use of diuretics, ACEI inhibitors or ARB was significantly higher in the lowest $\mathrm{SMg}$ quintile. Lower serum bicarbonate and albumin levels and higher BMI and CRP levels were also observed in the lowest SMg quintile (table 1).

\section{Univariable association of SMg levels with kidney function decline}

During a median follow-up of 7.0 years $(25 \mathrm{th}, 75$ th percentile: $6.5,7.6)$, the median eGFR change $(\Delta \mathrm{eGFR})$ was -0.71 (25th, 75 th percentile: $-2.43,+0.68) \mathrm{mL} / \mathrm{min} / 1.73 \mathrm{~m}^{2}$ per year in the entire cohort. When analyzing $\triangle \mathrm{eGFR}$ across $\mathrm{SMg}$ quintiles, the group with the lowest SMg quintile had a greater decline in eGFR compared with the highest $\mathrm{SMg}$ quintile during follow-up $(-1.08$ [25th, 75 th percentile: $-3.06,0.46$ ] vs -0.53 [25th, 75th percentile: $-1.96,0.97$ ] $\mathrm{mL} / \mathrm{min} / 1.73 \mathrm{~m}^{2}$ per year, respectively; $\mathrm{p}<0.001$; table 1 ).

There was a significant positive correlation between SMg levels and $\triangle \mathrm{eGFR}$ (table 2). Moreover, there was an inverse relationship between baseline SMg levels and CRP, DBP and SGlu levels (table 2). We also found that SBP and SGlu levels inversely correlated with $\triangle \mathrm{eGFR}$, and positively correlated with CRP (table 2).

\section{Multivariable association of SMg levels and decline in eGFR}

The lowest SMg quintile $(\leq 1.9 \mathrm{mg} / \mathrm{dL}$, or $\leq 0.8 \mathrm{mM})$ was associated with a $-0.50 \mathrm{~mL} / \mathrm{min} / 1.73 \mathrm{~m}^{2}$ per year decline in eGFR $(95 \%$ CI -0.95 to $-0.05 ; \mathrm{p}=0.028$ for lowest vs highest quintile) after adjustment for the major traditional risk factors for kidney function decline, including demographics, anthropometric and biochemical parameters, medications, CRP and prevalent hypertension and diabetes (table 3$)$. In the same fully adjusted model, every $0.2 \mathrm{mg} /$ $\mathrm{dL}(0.08 \mathrm{mM})$ decrease in $\mathrm{SMg}$ was associated with an eGFR decline of $-0.23 \mathrm{~mL} / \mathrm{min} / 1.73 \mathrm{~m}^{2}$ per year $(95 \% \mathrm{CI}$ -0.38 to $-0.08 ; \mathrm{p}=0.003$; table 6 ).

\section{Sensitivity analysis examining the association of SMg levels and decline in eGFR in study participants with and without prevalent diabetes}

Although the association remained significant after the inclusion of prevalent diabetes, a significant interaction between SMg and prevalent diabetes on the association between SMg levels and eGFR decline was observed $(p=0.02)$. Therefore, we stratified the study cohort based on prevalent diabetes at DHS-1. Participants with prevalent diabetes were older, mostly female $(59.4 \%)$, and a greater proportion was non-Hispanic black (65.2\%; table 4). They had higher BMI, SGlu, HDL, CRP; higher prevalence of comorbidities, including prevalent hypertension, and higher use of diuretics, ACEI and ARB. Mean SMg levels were significantly lower in participants with and without diabetes $(1.96 \pm 0.20$ vs $2.08 \pm 0.17 \mathrm{mg} / \mathrm{dL}$, or $0.81 \pm 0.08$ vs $0.86 \pm 0.07 \mathrm{mM}, \mathrm{p}<0.001$, respectively), whereas serum calcium and phosphate were similar. There was a significant positive correlation between SMg levels and $\triangle \mathrm{eGFR}$ in both subgroups, which was stronger in patients with diabetes than in patients without diabetes ( $r=0.25$ vs 0.06 , respectively; table 5). CRP was inversely correlated with $\mathrm{SMg}$, and positively correlated with SBP, DBP and SGlu in both subgroups. SGlu was inversely correlated with $\triangle \mathrm{eGFR}$ and SMg only in patients with diabetes. 


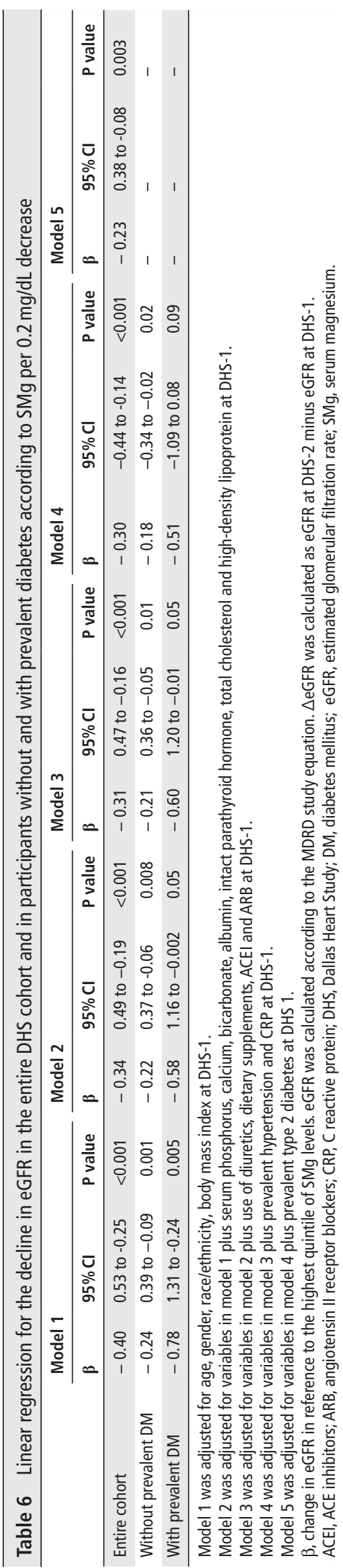

During follow-up, the decline in eGFR in participants with prevalent diabetes was higher than in participants without prevalent diabetes $(-1.97$ [25th, 75th percentile: $-3.79,-0.13]$ vs -0.64 [25th, 75 th percentile: $-2.28,+0.71] \mathrm{mL} / \mathrm{min} / 1.73 \mathrm{~m}^{2}$ per year, respectively, $\mathrm{p}<0.001$; table 4$)$. Every $0.2 \mathrm{mg} / \mathrm{dL}(0.08 \mathrm{mM})$ decrease in $\mathrm{SMg}$ was associated with a greater eGFR decline in participants with prevalent diabetes $\left(-0.51 \mathrm{~mL} / \mathrm{min} / 1.73 \mathrm{~m}^{2}\right.$ per year $[95 \% \mathrm{CI}-1.09$ to $+0.08 ; \mathrm{p}=0.09])$ vs those without prevalent diabetes $\left(-0.18 \mathrm{~mL} / \mathrm{min} / 1.73 \mathrm{~m}^{2}\right.$ per year $[95 \% \mathrm{CI}-0.34$, to $-0.02 ; \mathrm{p}=0.02])$ in fully adjusted models (table 6).

\section{DISCUSSION}

The principal finding of this study is that, in a large multiethnic population-based cohort, low SMg levels were associated with a greater decline in eGFR even after adjustment for the major traditional risk factors for kidney function decline, suggesting that low SMg may contribute to the pathogenesis of kidney disease and loss of renal function in a direct independent manner. Specifically, every $0.2 \mathrm{mg} / \mathrm{dL}$ $(0.08 \mathrm{mM})$ decrease in $\mathrm{SMg}$ was independently associated with an eGFR decline of $-0.23 \mathrm{~mL} / \mathrm{min} / 1.73 \mathrm{~m}^{2}$ per year during a median follow-up of 7.0 years in the entire cohort of DHS participants who did not have CKD at baseline. Moreover, the lowest SMg quintile $(\leq 1.9 \mathrm{mg} / \mathrm{dL}$ or $\leq 0.8 \mathrm{mM})$ was associated with a $-0.50 \mathrm{~mL} / \mathrm{min} / 1.73 \mathrm{~m}^{2}$ per year drop in eGFR $(95 \% \mathrm{CI}-0.95$ to $-0.05 ; \mathrm{p}=0.028)$ compared with the highest $\mathrm{SMg}$ quintile $(\geq 2.3 \mathrm{mg} / \mathrm{dL}$ or $\geq 1.0 \mathrm{mM})$ despite the lowest SMg quintile had the highest eGFR at baseline. Of note, the variations in SMg being evaluated in this study are within normal values $(1.6-2.6 \mathrm{mg} / \mathrm{dL})$. Only 16 out of 460 participants (3.5\%) in the lowest quintile had $\mathrm{SMg} \leq 1.6 \mathrm{mg} / \mathrm{dL}$, and 4 out of 460 participants $(0.9 \%)$ had $\mathrm{SMg}<1.6 \mathrm{mg} / \mathrm{dL}$. Thus, it is unlikely that study participants with $\mathrm{SMg}$ below the normal limit may drive the results observed in this study.

This eGFR decline was greater in participants with prevalent diabetes compared with those without prevalent diabetes $\left(-0.51 \mathrm{vs}-0.18 \mathrm{~mL} / \mathrm{min} / 1.73 \mathrm{~m}^{2}\right.$ per year, respectively). However, the adjusted association in participants with prevalent diabetes was borderline significant $(\mathrm{p}=0.09)$ probably due to the small number of subjects $(n=187$ subjects with prevalent diabetes vs $n=1869$ subjects without prevalent diabetes), which may have limited statistical power.

Other studies showed the association of $\mathrm{SMg}$ with markers of kidney function decline after controlling for diabetes. ${ }^{22} 2526$ Tin et al identified a large number of incident CKD cases $(n=1965)$ in the Atherosclerosis Risk in Communities (ARIC) study. ${ }^{22}$ They found that low $\mathrm{SMg}$ associated with incident CKD over a median follow-up of 21 years and after stratification by diabetes and hypertension. ${ }^{22}$ Compared with DHS, participants in the ARIC study were older (45-64 years in ARIC vs 30-65 years in DHS) and had longer follow-up (21 years in ARIC vs 7 years in DHS). In a multivariable regression analysis, Pham et al showed that in a small cohort of patients with diabetes $(n=550)$, low SMg associated with a faster rate of kidney function deterioration, as determined by the slope of serum creatinine over a mean follow-up of $5.2 \pm 1.9$ years. ${ }^{25} \mathrm{In}$ an 
adjusted analysis, Sakaguchi et al found that in a cohort of 455 patients with CKD those with diabetic CKD $(n=144)$ and low SMg levels had a significant higher risk of progression to renal replacement therapy compared with those with high SMg levels over a median follow-up of 1.9 years. ${ }^{26}$ In subjects with CKD and without diabetes, there was no significant difference in outcome between the low and high SMg groups. ${ }^{26}$

In our study, the decline in eGFR during follow-up was greater in participants with prevalent diabetes compared with subjects without prevalent diabetes as expected due to the underlying comorbidity. The positive correlation between SMg levels and $\triangle \mathrm{eGFR}$ was stronger in patients with diabetes than in patients without diabetes, which supports the observation of a greater eGFR decline for every $0.2 \mathrm{mg} /$ $\mathrm{dL}(0.08 \mathrm{mM})$ decrease in $\mathrm{SMg}$ in patients with diabetes than in patients without diabetes, even in a fully adjusted model. Of note, SMg levels were lower in participants with diabetes compared with participants without diabetes, a finding that has been previously shown in this patient population. ${ }^{3738}$ Whether low SMg is causative or a consequence of diabetes cannot be determined from this study, but epidemiological studies support a potential causal role of $\mathrm{Mg}$ in the development of diabetes possibly though hyperglycemia and/or inflammation..$^{39} 40$

Overall, the independent association of lower $\mathrm{SMg}$ levels with kidney function decline observed in the DHS cohort and in other cohorts may be explained at the molecular level by direct effects of $\mathrm{Mg}$ on renal and/or vascular cells. ${ }^{17241}$ Sakaguchi et al reported that, in a small group of non-diabetic CKD patients, subjects with high serum phosphate had a higher risk of ESRD when they had concomitant low SMg levels at baseline. ${ }^{24}$ They demonstrated that $\mathrm{Mg}$ suppresses phosphate-induced apoptosis of renal tubular cells in vitro experiments by inhibiting the expression of profibrotic and proinflammatory cytokines, and by inhibiting mitochondria-mediated cell death. ${ }^{24}$ In our study, the association of low $\mathrm{SMg}$ with eGFR decline was independent of serum phosphate, which was included as a confounding variable in our models. Besides a direct nephrotoxic effect, low extracellular $\mathrm{Mg}$ induces production of inflammatory and proatherogenic cytokines in endothelial cells, ${ }^{17}$ and promote vascular calcification in both in vitro and in vivo studies. ${ }^{41-43}$ Together these multiple molecular pathways can contribute to intrarenal chronic inflammation and impaired hemostasis that have been previously linked to kidney function decline. ${ }^{44-48}$

Some limitations of our study warrant mention. First, the number of patients with prevalent diabetes in our cohort is small. This may have limited statistical power after stratification for prevalent diabetes status. Second, this study is observational and thus cannot provide evidence of a causal relationship between SMg and kidney function decline. Our study has also several strengths. First, we used a large multiethnic population-based cohort with approximately $50 \%$ African- Americans, a population at high risk of CKD. Second, our cohort has an adequate median follow-up of 7.0 years for the observation of the outcome of eGFR decline, and is characterized by standardized longitudinal data collection methodology with a comprehensive biochemical phenotype assessment. Third, the availability of biomarkers of inflammation, BP and glycemic parameters underpinned important observations to construct plausible biological hypotheses that can guide further bench and clinical research.

In summary, we identified that low SMg is independently associated with eGFR decline in a large multiethnic cohort, and that the eGFR decline was greater in subjects with prevalent diabetes. Future studies are required to determine whether the modulation of SMg levels could represent a novel therapeutic target for the prevention of CKD in patients with and without diabetes who are at high risk of developing CKD.

\section{Author affiliations}

${ }^{1}$ Charles and Jane Pak Center for Mineral Metabolism and Clinical Research, UT Southwestern Medical Center, Dallas, TX, USA

2Department of Internal Medicine, Division of Mineral Metabolism, UT Southwestern Medical Center, Dallas, TX, USA

${ }^{3}$ Department of Clinical Sciences, Division of Biostatistics, UT Southwestern Medical Center, Dallas, TX, USA

${ }^{4}$ Department of Internal Medicine, Division of Nephrology, UT Southwestern Medical Center, Dallas, TX, USA

${ }^{5}$ Department of Physiology, UT Southwestern Medical Center, Dallas, TX, USA ${ }^{6}$ Department of Internal Medicine, Division of Nephrology, Bone and Mineral Metabolism, University of Kentucky, Lexington, KY, USA

Contributors Study concept and design: SF and JN. Acquisition, analysis or interpretation of data: SF, XL, BAH and JN. Drafting of the manuscript: SF and $J N$. Critical revision of the manuscript for intellectual content: NMM, KS, RT and OM. Statistical analysis: SF, XL, BAH and JN. Obtained funding: RT and OM. Study supervision: NMM, KS, RT, OM and JN.

Funding The Dallas Heart Study is supported by grant UL1TR001105 from the National Center for Advancing Translational Science of the National Institutes of Health. This work was also supported by the University of Texas Southwestern Medical Center O'Brien Kidney Research Center (P30DK079328). Dr Ferrè was supported by the Charles and Jane Pak Center Innovative Research Support Award. Dr Neyra is currently supported by an Early Career Pilot Grant from the National Center for Advancing Translational Sciences, National Institutes of Health, through Grant UL1TR001998.

Competing interests None declared.

Patient consent for publication Obtained.

Ethics approval The UT Southwestern Institutional Review Board approved the study.

Provenance and peer review Not commissioned; externally peer reviewed.

\section{REFERENCES}

1 Levey AS, Atkins R, Coresh J, et al. Chronic kidney disease as a global public health problem: approaches and initiatives - a position statement from kidney disease improving global outcomes. Kidney Int 2007;72:247-59.

2 Hill NR, Fatoba ST, Oke JL, et al. Global prevalence of chronic kidney disease - a systematic review and meta-analysis. PLoS One 2016;11:e0158765.

3 Stevens PE, Levin A. Evaluation and management of chronic kidney disease: synopsis of the kidney disease: improving global outcomes 2012 clinical practice guideline. Ann Intern Med 2013;158:825-30.

4 de Baaij JH, Hoenderop JG, Bindels RJ. Magnesium in man: implications for health and disease. Physiol Rev 2015;95:1-46.

5 Schulze MB, Schulz M, Heidemann C, et al. Fiber and magnesium intake and incidence of type 2 diabetes: a prospective study and meta-analysis. Arch Intern Med 2007;167:956-65.

6 Peacock JM, Folsom AR, Arnett DK, et al. Relationship of serum and dietary magnesium to incident hypertension: the Atherosclerosis Risk in Communities (ARIC) Study. Ann Epidemiol 1999;9:159-65.

7 He K, Liu K, Daviglus ML, et al. Magnesium intake and incidence of metabolic syndrome among young adults. Circulation 2006;113:1675-82.

8 Chacko SA, Song Y, Nathan L, et al. Relations of dietary magnesium intake to biomarkers of inflammation and endothelial dysfunction in an ethnically diverse cohort of postmenopausal women. Diabetes Care 2010;33:304-10.

9 Song Y, Li TY, van Dam RM, et al. Magnesium intake and plasma concentrations of markers of systemic inflammation and endothelial dysfunction in women. Am J Clin Nutr 2007;85:1068-74. 
10 Liao F, Folsom AR, Brancati FL. Is low magnesium concentration a risk factor for coronary heart disease? The Atherosclerosis Risk in Communities (ARIC) Study. Am Heart J 1998;136:480-90.

11 Zhang W, Iso H, Ohira T, et al. Associations of dietary magnesium intake with mortality from cardiovascular disease: the JACC study. Atherosclerosis 2012;221:587-95.

12 Larsson SC, Orsini N, Wolk A. Dietary magnesium intake and risk of stroke: a meta-analysis of prospective studies. Am I Clin Nutr 2012;95:362-6.

13 Ohira T, Peacock JM, Iso H, et al. Serum and dietary magnesium and risk of ischemic stroke: the atherosclerosis risk in communities study. Am J Epidemiol 2009;169:1437-44.

14 Günther T. The biochemical function of $\mathrm{Mg}^{2}+$ in insulin secretion, insulin signal transduction and insulin resistance. Magnes Res 2010;23:5-18.

15 Reis MA, Reyes FG, Saad MJ, et al. Magnesium deficiency modulates the insulin signaling pathway in liver but not muscle of rats. J Nutr 2000;130:133-8.

16 Suárez A, Pulido N, Casla A, et al. Impaired tyrosine-kinase activity of muscle insulin receptors from hypomagnesaemic rats. Diabetologia 1995;38:1262-70.

17 Ferrè S, Baldoli E, Leidi M, et al. Magnesium deficiency promotes a proatherogenic phenotype in cultured human endothelial cells via activation of NFkB. Biochim Biophys Acta 2010;1802:952-8.

18 Weglicki WB, Phillips TM, Freedman AM, et al. Magnesium-deficiency elevates circulating levels of inflammatory cytokines and endothelin. Mol Cell Biochem 1992;110:169-73.

19 Yang ZW, Gebrewold A, Nowakowski M, et al. Mg(2+)-induced endotheliumdependent relaxation of blood vessels and blood pressure lowering: role of NO. Am J Physiol Regul Integr Comp Physiol 2000;278:R628-39.

20 Briel RC, Lippert TH, Zahradnik HP. Action of magnesium sulfate on platelet prostacyclin interaction and prostacyclin of blood vessels. Am J Obstet Gynecol 1985;153:232.

21 Wolf Fl, Trapani V, Simonacci M, et al. Magnesium deficiency and endothelial dysfunction: is oxidative stress involved? Magnes Res 2008;21:58-64.

22 Tin A, Grams ME, Maruthur NM, et al. Results from the atherosclerosis risk in communities study suggest that low serum magnesium is associated with incident kidney disease. Kidney Int 2015;87:820-7.

23 Van Laecke S, Nagler EV, Verbeke F, et al. Hypomagnesemia and the risk of death and GFR decline in chronic kidney disease. Am J Med 2013;126:825-31.

24 Sakaguchi Y, Iwatani H, Hamano T, et al. Magnesium modifies the association between serum phosphate and the risk of progression to end-stage kidney disease in patients with non-diabetic chronic kidney disease. Kidney Int 2015;88:833-42.

25 Pham PC, Pham PM, Pham PA, et al. Lower serum magnesium levels are associated with more rapid decline of renal function in patients with diabetes mellitus type 2. Clin Nephrol 2005;63:429-36.

26 Sakaguchi Y, Shoji T, Hayashi T, et al. Hypomagnesemia in type 2 diabetic nephropathy: a novel predictor of end-stage renal disease. Diabetes Care 2012;35:1591-7.

27 Ferrè S, Li X, Adams-Huet B, et al. Association of serum magnesium with all-cause mortality in patients with and without chronic kidney disease in the dallas heart study. Nephrol Dial Transplant 2018;33:1389-1396.

28 Kanbay M, Yilmaz MI, Apetrii M, et al. Relationship between serum magnesium levels and cardiovascular events in chronic kidney disease patients. Am J Nephrol 2012;36:228-37.

29 Lacson E, Wang W, Ma L, et al. Serum magnesium and mortality in hemodialysis patients in the united states: a cohort study. Am J Kidney Dis 2015;66:1056-66.
30 Sakaguchi Y, Fujii N, Shoji T, et al. Hypomagnesemia is a significant predictor of cardiovascular and non-cardiovascular mortality in patients undergoing hemodialysis. Kidney Int 2014;85:174-81.

31 Sakaguchi Y, Hamano T, Nakano C, et al. Association between density of coronary artery calcification and serum magnesium levels among patients with chronic kidney disease. PLoS One 2016;11:e0163673.

32 de Roij van Zuijdewijn CL, Grooteman MP, Bots ML, et al. Serum magnesium and sudden death in European hemodialysis patients. PLoS One 2015;10:e0143104.

33 Victor RG, Haley RW, Willett DL, et al. The Dallas Heart Study: a populationbased probability sample for the multidisciplinary study of ethnic differences in cardiovascular health. Am J Cardiol 2004;93:1473-80.

34 Neeland IJ, Turer AT, Ayers CR, et al. Dysfunctional adiposity and the risk of prediabetes and type 2 diabetes in obese adults. JAMA 2012;308:1150-9.

35 Levey AS, Bosch JP, Lewis JB, et al. A more accurate method to estimate glomerular filtration rate from serum creatinine: a new prediction equation. Modification of diet in renal disease study group. Ann Intern Med 1999;130:461-70.

36 Roberts WL, Moulton L, Law TC, et al. Evaluation of nine automated high-sensitivity C-reactive protein methods: implications for clinical and epidemiological applications. Part 2. Clin Chem 2001:47:418-25.

37 Pham PC, Pham PM, Pham SV, et al. Hypomagnesemia in patients with type 2 diabetes. Clin J Am Soc Nephrol 2007;2:366-73.

38 Kurstjens $\mathrm{S}$, de Baaij JH, Bouras $\mathrm{H}$, et al. Determinants of hypomagnesemia in patients with type 2 diabetes mellitus. Eur J Endocrinol 2017;176:11-19.

39 Kao WH, Folsom AR, Nieto FJ, et al. Serum and dietary magnesium and the risk for type 2 diabetes mellitus: the atherosclerosis risk in communities study. Arch Intern Med 1999;159:2151-9.

40 Kieboom BCT, Ligthart S, Dehghan A, et al. Serum magnesium and the risk of prediabetes: a population-based cohort study. Diabetologia 2017;60:843-53.

41 Montezano AC, Zimmerman D, Yusuf $H$, et al. Vascular smooth muscle cell differentiation to an osteogenic phenotype involves TRPM7 modulation by magnesium. Hypertension 2010;56:453-62.

42 Ter Braake AD, Tinnemans PT, Shanahan CM, et al. Magnesium prevents vascular calcification in vitro by inhibition of hydroxyapatite crystal formation. Sci Rep 2018;8:2069.

43 Montes de Oca A, Guerrero F, Martinez-Moreno JM, et al. Magnesium inhibits $\mathrm{Wnt} / \beta$-catenin activity and reverses the osteogenic transformation of vascular smooth muscle cells. PLoS One 2014;9:e89525.

44 Upadhyay A, Larson MG, Guo CY, et al. Inflammation, kidney function and albuminuria in the Framingham Offspring cohort. Nephrol Dial Transplant 2011;26:920-6.

45 Hiramoto JS, Katz R, Peralta CA, et al. Inflammation and coagulation markers and kidney function decline: the Multi-Ethnic Study of Atherosclerosis (MESA). Am J Kidney Dis 2012;60:225-32.

46 Shankar A, Sun L, Klein BE, et al. Markers of inflammation predict the longterm risk of developing chronic kidney disease: a population-based cohort study. Kidney Int 2011;80:1231-8.

47 Keller C, Katz R, Sarnak MJ, et al. Inflammatory biomarkers and decline in kidney function in the elderly: the Cardiovascular Health Study. Nephrol Dial Transplant 2010;25:119-24.

48 Bash LD, Erlinger TP, Coresh J, et al. Inflammation, hemostasis, and the risk of kidney function decline in the Atherosclerosis Risk in Communities (ARIC) Study. Am J Kidney Dis 2009;53:596-605. 